\title{
HUBUNGAN PENGETAHUAN DAN SIKAP RESPONSIVE FEEDING DENGAN KEJADIAN STUNTING PADA BADUTA USIA 6-24 BULAN DI WILAYAH KERJA PUSKESMAS BANDARHARJO, SEMARANG
}

\author{
Risna Galuh Septamarini, Nurmasari Widyastuti*, Rachma Purwanti \\ Departemen Ilmu Gizi, Fakultas Kedokteran, Universitas Diponegoro \\ Jln. Prof. H. Soedarto, SH., Semarang, Telp (024) 76402881, Email : gizifk@undip.ac.id
}

\begin{abstract}
Background : Stunting is a form of malnutrition characterized by indicators H/A and are most at risk occurred during the first two years of age. Factors that influence one of them is intake, which is mothers had an important role to the intake through feeding patterns, one with Responsive Feeding (RF). RF in Indonesia since the age of 6 months and older is still not optimal.

Aim : Determine the relationship between knowledge and attitudes of RF with stunting on children aged 6-24 months. Method: Observational research with case control approach in Puskesmas Bandarharjo Semarang. Number of samples 32 baduta in case group and 32 baduta in control group, were selected by purposive sampling with matching. Data collected includes: sample characteristics, maternal characteristics, knowledge and attitudes mother of RF. Body weight was measured using a baby scale and height were measured using a length board. The intake of energy, protein, zinc obtained from semi-quantitative - food frequency questionairre (SQ-FFQ). Data were analyzed by univariate analysis, bivariate analysis used Chi Square test, and OR to determine the risk.

Results: The prevalence of baduta stunted in Kelurahan Bandarharjo 22.6\%. The knowledge and attitude of the RF case group was 59.4\% low, 68.7\% was not appropriate, in the control group $87.5 \%$ was sufficient, $72.9 \%$ was quite appropriate. There was a relationship between knowledge and attitudes of RF with stunting in baduta aged 6-24 months. $(p=0,000 ; O R=10.2 ; C I=3.76-27.75) ;(p=0.003 ; O R=5.6 ; C I=2.17-21.67)$

Conclusion: There was a relationship between knowledge and attitude of $R F(O R=5.6)$ with stunting on children aged 6-24 months. Mothers with low RF knowledge 10.2 times greater risk of having stunted children than mothers with sufficient knowledge. Mothers with less RF appropriate attitude 5.6 times greater risk of having stunted children compared with mothers who had sufficient RF attitude.
\end{abstract}

Keywords : stunting, knowledge, attitude, responsive feeding, baduta

\begin{abstract}
ABSTRAK
Latar Belakang : Stunting merupakan wujud gizi kurang yang ditandai dengan indikator PB/U dan paling berisiko terjadi pada masa dua tahun pertama usia anak. Faktor yang mempengaruhi salah satunya adalah asupan dimana ibu memiliki peran penting terhadap asupan melalui pola pemberian makan, salah satunya dengan Responsive Feeding (RF). Praktik RF di Indonesia sejak usia 6 bulan keatas masih belum optimal.

Tujuan : Mengetahui hubungan antara pengetahuan dan sikap RF dengan kejadian stunting pada baduta usia 6-24 bulan.

Metode : Penelitian observasional dengan pendekatan case control di Wilayah Puskesmas Bandarharjo Semarang. Banyak subjek kelompok kasus 32 baduta dan kelompok konrol 32 baduta, dipilih secara purposive sampling dengan matching. Data yang dikumpulkan meliputi: karakteristik subjek, karakteristik ibu, pengetahuan serta sikap RF ibu. Berat badan diukur menggunakan baby scale dan tinggi badan diukur menggunakan length board. Asupan energi, protein, seng diperoleh dari semi quantitatif - food frequency questionairre (SQ-FFQ). Data dianalisis dengan uji analisis univariat, analisis bivariat menggunakan uji Chi Square, dan OR untuk mengetahui besar risiko.

Hasil : Prevalensi baduta stunting di Kelurahan Bandarharjo 22,6\%. Rerata pengetahuan dan sikap RF kelompok kasus 59,4\% rendah, 68,7\% kurang sesuai, pada kelompok kontrol 87,5\% cukup, 72,9\% cukup sesuai. Terdapat hubungan antara pengetahuan dan sikap $R F$ dengan kejadian stunting pada baduta usia 6-24 bulan ( $p=0,000 ; O R=10,2 ; C I=3,76$ 27,75); $(p=0,003 ; O R=5,6 ; C I=2,17-21,67)$

Simpulan : Terdapat hubungan antara pengetahuan dan sikap RF dengan kejadian stunting pada baduta usia 6-24 bulan. Ibu dengan pengetahuan RF rendah berisiko 10,2 kali lebih besar memiliki anak stunting dibandingkan dengan ibu berpengetahuan cukup. Ibu dengan sikap RF kurang sesuai berisiko 5,6 kali lebih besar memiliki anak stunting dibandingkan dengan ibu yang memiliki sikap $R F$ yang cukup.
\end{abstract}

Kata kunci : kejadian stunting, pengetahuan, sikap, responsive feeding, baduta 


\section{PENDAHULUAN}

Stunting merupakan salah satu wujud gizi kurang yang ditandai dengan indikator $\mathrm{PB} / \mathrm{U}$ kurang dari -2SD berisiko mengalami kematian empat kali lebih besar pada usia kurang dari lima tahun dibandingkan dengan anak berstatus gizi baik ${ }^{1}$. Secara nasional, prevalensi stunting baduta di Indonesia mengalami peningkatan dari Tahun 2007 yaitu sebesar $38,2 \%$ menjadi sebesar $39,2 \%$ pada Tahun 2013. Sedangkan prevalensi stunting di Jawa Tengah mencapai $37,2 \%{ }^{2}$. Stunting paling berisiko terjadi pada masa dua tahun pertama usia anak, yang merupakan masa dimana anak mengalami perkembangan otak dan pertumbuhan linear yang pesat $^{3,4}$. Stunting masih dapat diperbaiki jika terjadi pada dua tahun pertama usia anak, namun setelahnya akan sulit untuk diperbaiki. Penyebab stunting antara lain adalah karena genetik, panjang badan lahir, kurangnya asupan makan, infeksi, karakteristik ibu dan status ekonomi ${ }^{5-8}$.

Pola asuh dalam pemberian makan pada anak menurut beberapa penelitian berpotensi menyebabkan stunting dan terbukti adanya hubungan antara keduanya ${ }^{9,10}$. Pemberian makan untuk anak usia 6-24 bulan harus diperhatikan baik secara kualitas maupun kuantitas karena pada masa ini juga turut ditanamkan tahap serta jenis makanan ${ }^{11}$. Anak akan susah mengonsumsi makanan pendamping pada periode ini karena adanya perubahan makanan dari hanya ASI menjadi ASI ditambah makanan lumat dan lunak, serta perkenalan terhadap makanan keluarga untuk anak usia lebih dari satu tahun. Asupan makanan dengan kualitas rendah pada anak merupakan gambaran langsung dari pemilihan makanan orangtua yang diberikan kepada anak ${ }^{12}$.

Ibu memiliki peran penting dalam asupan dan perkembangan terhadap perilaku makan anak melalui pola pemberian makan, salah satunya adalah dengan Responsive feeding $(R F)$ sebagaimana telah diatur oleh WHO dan UNICEF ${ }^{13,14}$. Responsive feeding merupakan kemampuan pengasuh untuk memberi makan anak secara aktif dan responsif termasuk di dalamnya cara pemberian makan sesuai umur, memberikan contoh kebiasaan yang sehat, mendorong anak untuk makan, berespon terhadap nafsu makan yang kurang, memberi makan di lingkungan yang aman, dan menggunakan interaksi yang positif ${ }^{15}$. Responsive feeding berhubungan dengan ketertarikan anak terhadap makanan yang mempengaruhi asupan dari segi kualitas dan kuantitas sehingga dapat berimbas pada status gizi ${ }^{16}$. Dampak positif dari responsive feeding yaitu mampu meningkatkan penerimaan makanan dan kemampuan makan sendiri ${ }^{16,17}$. Selain itu responsive feeding memasukkan konsep psikososial yang baik untuk perkembangan mental maupun kognitif anak ${ }^{13,14,18}$.
Penelitian membuktikan praktik RF di Indonesia sejak usia 6 bulan ke atas belum optimal karena hanya $30 \%$ dari pengasuh yang mempraktikkan RF dan menjadi salah satu hambatan dalam mengurangi masalah stunting hingga saat ini ${ }^{19}$. Selain itu, peningkatan pengetahuan terbukti mampu meningkatkan kualitas pemberian makan sehingga menggambarkan bahwa pengetahuan penting dalam menentukan sikap dan perilaku pengasuh dalam pemberian makan ${ }^{20}$. Pengetahuan RF pengasuh dapat berupa identifikasi ke enam prinsip dasar serta dalam kondisi tertentu sehingga pemenuhan gizi pada anak dapat tercapai ${ }^{18}$.

Berdasarkan hasil pemantauan status gizi berdasarkan indikator $\mathrm{PB} / \mathrm{U}$ atau $\mathrm{TB} / \mathrm{U}$ Dinas Kesehatan Kota Semarang diketahui kejadian balita stunting mencapai 20,37\% dengan kejadian tertinggi pada tahun 2017 di wilayah kerja Puskesmas Bandarharjo $^{21}$. Penelitian ini mengambil lokasi di Wilayah Kerja Puskesmas Bandarharjo Semarang Utara hal ini dikarenakan tingginya anak usia 6-24 bulan yang berstatus gizi stunting. Berdasarkan uraian masalah tersebut maka peneliti tertarik untuk melakukan penelitian yang bertujuan mengetahui hubungan pengetahuan dan sikap RF ibu dengan kejadian stunting pada baduta usia $6-24$ bulan di Wilayah Kerja Puskesmas Bandarharjo.

\section{METODE}

Penelitian ini dilaksanakan di Wilayah Kerja Puskesmas Bandarharjo Semarang Utara pada bulan Mei - Agustus 2018. Penelitian ini merupakan penelitian observasional dengan rancangan penelitian case control, dengan rasio 1:1. Pelaksanaan penelitian ini telah memperoleh persetujuan dari Komite Etik Penelitian Kesehatan (KEPK) Fakultas Kedoteran Universitas Diponegoro/Rumah Sakit Umum Pusat dr. Kariadi No. 515/EC/FKRSDK/VII/2018. Populasi target dalam penelitian ini adalah baduta usia 6-24 bulan, sedangkan populasi terjangkaunya adalah baduta usia 6-24 bulan di Wilayah Kerja Puskesmas Bandarharjo Semarang Utara. Pemilihan subjek penelitian kelompok kasus menggunakan purposive sampling dimana pengambilan subjek secara sengaja sesuai dengan persyaratan subjek yang diperlukan, sedangkan kelompok kontrol dipilih menggunakan matching jenis kelamin dan usia.

Besar sampel untuk kelompok kasus (kelompok stunting) adalah 32 baduta dan kelompok kontrol (kelompok normal) adalah 32 baduta. Subjek penelitian kelompok kasus memenuhi kriteria inklusi yaitu: (1) Baduta usia 6-24 bulan dengan Z-score $\mathrm{PB} / \mathrm{U}<-2 \mathrm{SD}, \mathrm{BB} / \mathrm{U}$ dan BB/PB 2 SD hingga $-2 \mathrm{SD}$ (2) Baduta tidak infeksi dan tidak dirawat di rumah sakit. Subjek penelitian kelompok kontrol memenuhi 
kriteria inklusi yaitu: (1) Baduta usia 6-24 bulan dengan Z-score $\mathrm{PB} / \mathrm{U}, \mathrm{BB} / \mathrm{U}$ dan $\mathrm{BB} / \mathrm{PB} 2 \mathrm{SD}$ hingga -2 SD (2) Baduta tidak infeksi dan tidak dirawat di rumah sakit. Responden yang memenuhi kriteria inklusi : (1) ibu rumah tangga yang mengasuh anaknya sendiri, (2) ibu baduta bersedia mengisi informed consent dan berpartisipasi dalam penelitian, (3) ibu baduta dapat berkomunikasi dengan jelas. Kriteria eksklusi responden terdiri dari (1) ibu mengundurkan diri dalam penelitian, (2) data tidak lengkap, (3) ibu dalam kondisi sakit sehingga tidak dapat melanjutkan menjadi subjek. Variabel bebas dalam penelitian ini adalah pengetahuan dan sikap responsive feeding, variabel terikat adalah stunting pada baduta 6-24 bulan dan variabel perancu dalam penelitian ini adalah panjang badan lahir, asupan energi, protein, dan seng, dan karakteristik ibu (TB ibu, usia hamil, pendidikan terakhir, pendapatan keluarga).

Tahapan dalam penelitian ini meliputi uji validitas dan reabilitas kuesioner, skrining, wawancara kuesioner, analisis data, dan pembuatan laporan. Pengujian kuesioner dilakukan pada 15 responden di wilayah Kelurahan Bandarharjo. Berdasarkan hasil pengujian validitas $r$ hitung lebih besar dari 0,25 dan reabilitas nilai cronbach alpha lebih dari 0,6 didapatkan masing-masing 22 pertanyaan pengetahuan RF dan sikap RF. Pengukuran antropometri pada skrining yang dilakukan berupa pengukuran tinggi badan menggunakan length board dengan ketelitian $0,1 \mathrm{~cm}$, berat badan menggunakan baby scale dengan ketelitian $0,1 \mathrm{~kg}$. Subjek yang masuk ke dalam kelompok stunting memiliki z-score $\mathrm{PB} / \mathrm{U}<-2 \mathrm{SD}$ dan subjek yang masuk kedalam kelompok normal memiliki z-score PB/U -2 SD hingga 2 SD. Subjek yang menjadi subjek diambil data pengetahuan dan sikap terhadap RF.

Asupan energi, protein, dan seng diperoleh dengan wawancara menggunakan Semi QuantitativeFood Frequency Questionnaire (SQ-FFQ). Hasil analisis asupan protein dinyatakan dalam gram. Analisis asupan menggunakan aplikasi Nutrisurvey 2007. Setelah dianalisis, dibandingkan dengan kebutuhan asupan masing-masing individu. Kebutuhan energi dihitung dengan menggunakan rumus Nelson. Analisis asupan seng menggunakan AKG 2013 untuk usia 6-24 bulan. Tingkat asupan zat gizi dibagi menjadi 2 kategori yaitu asupan kurang (< $80 \%$ dari kebutuhan individu) dan dikategorikan cukup ( $\geq 80 \%$ dari kebutuhan individu) ${ }^{22}$.

Analisis data dilakukan dengan menggunakan program komputer. Analisis univariat digunakan untuk menganalisis nilai minimal, maksimal, rata-rata dalam penelitian dengan melihat gambaran distribusi frekuensi dan proporsi. Analisis bivariat menggunakan uji Chi Square untuk mengetahui ada tidaknya hubungan yang bermakna antara pengetahuan $\mathrm{RF}$, sikap RF, dan variabel perancu dengan kejadian stunting, serta menghitung nilai OR untuk mengetahui besar risiko setiap variabel.

Tabel 1. Karakteristik Subjek Penelitian

\begin{tabular}{|c|c|c|c|c|c|c|c|c|}
\hline \multirow{2}{*}{ Variabel } & \multicolumn{4}{|c|}{ Kasus } & \multicolumn{4}{|c|}{ Kontrol } \\
\hline & n $(\%)$ & Min & $\operatorname{Max}$ & Mean \pm SD & n (\%) & Min & $\operatorname{Max}$ & Mean \pm SD \\
\hline Usia & & 6 & 23 & $15,28 \pm 4,81$ & & 6 & 23 & $15,28 \pm 4,81$ \\
\hline $6-12$ bulan & $12(37,5)$ & & & & $12(37,5)$ & & & \\
\hline $13-24$ bulan & $20(62,5)$ & & & & $20(62,5)$ & & & \\
\hline Jenis Kelamin & & & & & & & & \\
\hline Laki-laki & $15(46,8)$ & & & & $15(46,8)$ & & & \\
\hline Perempuan & $17(53,2)$ & & & & $17(53,2)$ & & & \\
\hline $\mathrm{PB} / \mathrm{U}$ & & $-4,32$ & $-2,03$ & $-2,65 \pm 0,59$ & & $-1,99$ & 1,27 & $-0,89 \pm 0,96$ \\
\hline Normal & $0(0)$ & & & & $32(100)$ & & & \\
\hline Stunting & $32(100)$ & & & & $0(0)$ & & & \\
\hline Panjang Badan Lahir & & 44 & 51 & $48,13 \pm 1,86$ & & 42 & 50 & $47,97 \pm 2,31$ \\
\hline Kurang & $16(50)$ & & & & $14(43,8)$ & & & \\
\hline Normal & $16(50)$ & & & & $18(56,2)$ & & & \\
\hline Asupan Energi (\%) & & 29,76 & 143,91 & $82,78 \pm 32,62$ & & 68,09 & 138,32 & $96,15 \pm 21,109$ \\
\hline Kurang & $15(46,8)$ & & & & $6(18,8)$ & & & \\
\hline Cukup & $17(53,2)$ & & & & $26(81,2)$ & & & \\
\hline Asupan Protein (\%) & & 20,28 & 240,63 & $96,32 \pm 61,23$ & & 33,89 & 336,81 & $123,02 \pm 72,70$ \\
\hline Kurang & $13(40,7)$ & & & & $9(28,1)$ & & & \\
\hline Cukup & $19(59,3)$ & & & & $23(72,9)$ & & & \\
\hline Asupan Seng (\%) & & 17,5 & 700 & $171,80 \pm 186,93$ & & 40 & 720 & $184,97 \pm 145,38$ \\
\hline Kurang & $13(40,7)$ & & & & $7(28)$ & & & \\
\hline Cukup & $19(59,3)$ & & & & $25(72)$ & & & \\
\hline
\end{tabular}




\section{HASIL}

\section{Karakteristik Subjek}

Jumlah subjek dalam penelitian ini sebanyak 64 anak baduta yang terdiri dari 32 anak stunting dan 32 anak normal. Berdasarkan tabel karakteristik subjek (tabel 1) diketahui sebanyak $46,8 \%$ subjek berjenis kelamin laki-laki dan 53,2\% berjenis kelamin perempuan serta $37,5 \%$ subjek berusia $6-12$ bulan dan $62,5 \%$ berusia 13-24 bulan.

Tabel 1 menunjukkan bayi dengan panjang badan lahir rendah paling banyak pada kelompok stunting. Bayi dengan panjang lahir rendah $(<48 \mathrm{~cm})$ dan normal pada kelompok stunting sebanding. Asupan energi, protein, dan seng yang kurang $(<80 \%)$ paling banyak terdapat pada kelompok stunting.

\section{Karakteristik Ibu}

Berdasarkan karakteristik ibu yang ditunjukkan pada tabel 2, usia pada saat hamil berisiko $(<21$ tahun atau $>35$ tahun) paling tinggi terdapat pada kelompok kasus, sedangkan ibu dengan tinggi badan pendek paling banyak terdapat pada kelompok kasus. Pada kelompok kasus, lebih banyak ibu berpendidikan dasar dibandingkan kelompok kontrol. Pendidikan tingkat dasar terendah adalah tidak bersekolah.

Tabel 2. Karakteristik Ibu

\begin{tabular}{|c|c|c|c|c|c|c|c|c|}
\hline \multirow{2}{*}{ Variabel } & \multicolumn{4}{|c|}{ Kasus } & \multicolumn{4}{|c|}{ Kontrol } \\
\hline & n (\%) & Min & Max & Mean \pm SD & $\mathrm{n}(\%)$ & Min & Max & Mean \pm SD \\
\hline Usia hamil & & 17 & 40 & $25,44 \pm 5,37$ & & 17 & 43 & $27,69 \pm 6,70$ \\
\hline $\begin{array}{l}\text { Berisiko } \\
(<21 \text { tahun atau }>35 \text { tahun })\end{array}$ & $8(25)$ & & & & $7(21,8)$ & & & \\
\hline Tidak berisiko & $24(75)$ & & & & $25(72)$ & & & \\
\hline Tinggi Ibu & & 147,5 & 162 & $152,86 \pm 2,99$ & & 148,0 & 161,7 & $154,49 \pm 3,03$ \\
\hline Normal & $27(84,4)$ & & & & $29(90,6)$ & & & \\
\hline Pendek $(<150 \mathrm{~cm})$ & $5(15,6)$ & & & & $3(9,4)$ & & & \\
\hline Pendidikan & & & & & & & & \\
\hline $\begin{array}{l}\text { Dasar } \\
\text { (tidak sekolah, SD, SMP) }\end{array}$ & $10(31,3)$ & & & & $9(28,1)$ & & & \\
\hline $\begin{array}{l}\text { Tinggi } \\
\text { (SMA, Diploma) }\end{array}$ & $22(68,7)$ & & & & $23(72,9)$ & & & \\
\hline Pendapatan keluarga (ribu ru & Ipiah) & 1000 & 5500 & $2105 \pm 756$ & & 0 & 2750 & $1962 \pm 601$ \\
\hline Rendah (<UMR) & $18(56,2)$ & & & & $17(53,2)$ & & & \\
\hline Cukup ( $\geq$ UMR) & $14(43,8)$ & & & & $15(46,8)$ & & & \\
\hline Pengetahuan $R F$ & & 36 & 82 & $61,51 \pm 10,95$ & & 50 & 95 & $79,26 \pm 11,77$ \\
\hline Kurang $(\leq 60)$ & $19(59,4)$ & & & & $4(12,5)$ & & & \\
\hline Cukup & $13(40,6)$ & & & & $28(87,5)$ & & & \\
\hline Sikap $R F$ & & 54 & 84 & $61,96 \pm 6,28$ & & 56 & 85 & $65,45 \pm 6,28$ \\
\hline Kurang $(\leq 60)$ & $22(68,7)$ & & & & $9(28,1)$ & & & \\
\hline Cukup & $10(31,3)$ & & & & $23(72,9)$ & & & \\
\hline
\end{tabular}

Tingkat pendapatan keluarga termasuk cukup apabila sama atau melebihi UMR Kota Semarang yaitu $\mathrm{Rp} 2.310 .000,00$. Tabel 2 menunjukkan ibu dengan pendapatan keluarga rendah paling banyak terdapat pada kelompok stunting. Tingkat pengetahuan RF terendah dan tingkat sikap RF terendah paling banyak terdapat pada kelompok stunting.

\section{Analisis Bivariat}

Hasil analisis hubungan antara faktor-faktor yang berisiko terhadap kejadian stunting dapat dilihat pada tabel 3.

Berdasarkan tabel analisis chi-square (tabel 3) diketahui bahwa terdapat hubungan antara pengetahuan $\mathrm{RF}(\mathrm{p}=0.000)$ dengan kejadian stunting pada baduta usia 6-24 bulan. Ibu dengan pengetahuan RF yang rendah berisiko 10,2 kali lebih besar anak mengalami stunting dibandingkan dengan ibu berpengetahuan cukup. Analisis chi-square diketahui bahwa terdapat hubungan antara sikap RF $(\mathrm{p}=0.003)$ dengan kejadian stunting pada baduta usia 6-24 bulan. Ibu dengan sikap RF yang kurang berisiko 5,6 kali lebih besar anak mengalami kejadian stunting dibandingkan dengan ibu yang memiliki sikap RF yang cukup.

Penelitian ini tidak dipengaruhi oleh variabel perancu, ditunjukkan dengan tidak adanya hubungan antara asupan energi, asupan protein, dan asupan seng dengan kejadian stunting $(\mathrm{p}>0.005)$. Namun demikian, terdapat kecenderungan bahwa anak yang mengonsumsi energi, protein, seng yang kurang berisiko lebih tinggi mengalami stunting dibandingkan anak yang mengonsumsi energi, protein, dan seng yang cukup $(\mathrm{OR}=3.3, \mathrm{OR}=1.7$, dan $\mathrm{OR}=2.4$ ) meskipun secara statistik tidak bermakna. Tidak adanya hubungan antara usia saat hamil, tinggi ibu, pendidikan terakhir dan pendapatan keluarga dengan kejadian stunting juga menunjukkan 
penelitian ini tidak dipengaruhi variabel perancu karakteristik ibu. Namun demikian, terdapat kecenderungan bahwa ibu dengan tinggi badan kurang, pendidikan dasar, dan pendapatan keluarga kurang berisiko lebih tinggi anak mengalami stunting dibandingkan ibu dengan tinggi badan normal, pendidikan tinggi, dan pendapatan keluarga cukup $(\mathrm{OR}=1.7, \mathrm{OR}=1.2$, dan $\mathrm{OR}=1.1)$ meskipun secara statistik tidak bermakna. Usia hamil ibu tidak berisiko yaitu antara usia 20 tahun sampai dengan 30 tahun merupakan faktor protektif dari kejadian stunting $(\mathrm{OR}<1)$.

Tabel 3. Faktor yang Berisiko terhadap Kejadian Stunting

\begin{tabular}{|c|c|c|c|c|c|c|c|c|}
\hline \multirow{2}{*}{ Variabel } & \multicolumn{2}{|c|}{ Stunting } & \multicolumn{2}{|c|}{ Normal } & \multirow{2}{*}{$\mathbf{P}$} & \multirow{2}{*}{ OR } & \multicolumn{2}{|c|}{$90 \% \mathrm{CI}$} \\
\hline & n & $\%$ & n & $\%$ & & & $\min$ & $\max$ \\
\hline Panjang Badan Lahir & & & & & $0,802^{\mathrm{a}}$ & 1,29 & 0,29 & 2,08 \\
\hline Kurang & 16 & 50 & 14 & 43,8 & & & & \\
\hline Normal & 16 & 50 & 18 & 56,2 & & & & \\
\hline Asupan Energi & & & & & $0,330^{\mathrm{a}}$ & 3,28 & 1,25 & 12,61 \\
\hline Kurang & 15 & 46,8 & 6 & 18,8 & & & & \\
\hline Cukup & 17 & 53,2 & 26 & 81,2 & & & & \\
\hline Asupan Protein & & & & & $0,430^{\mathrm{a}}$ & 1,75 & 0,57 & 5,01 \\
\hline Kurang & 13 & 40,7 & 9 & 28,1 & & & & \\
\hline Cukup & 19 & 59,3 & 23 & 72,9 & & & & \\
\hline Asupan Seng & & & & & $0,178^{\mathrm{a}}$ & 2,44 & 1,02 & 7,10 \\
\hline Kurang & 13 & 40,7 & 7 & 21,8 & & & & \\
\hline Cukup & 19 & 59,3 & 25 & 78,2 & & & & \\
\hline Usia hamil & & & & & $0,087^{\mathrm{a}}$ & 1,19 & 0,43 & 5,24 \\
\hline $\begin{array}{l}\text { Berisiko } \\
(<21 \text { tahun atau }>35 \text { tahun })\end{array}$ & 8 & 25 & 7 & 21,8 & & & & \\
\hline Tidak berisiko & 24 & 75 & 25 & 78,2 & & & & \\
\hline Tinggi Ibu & & & & & $0,555^{\mathrm{a}}$ & 1,69 & 0,70 & 5,78 \\
\hline Normal & 27 & 84,4 & 29 & 90,6 & & & & \\
\hline Pendek $(<150 \mathrm{~cm})$ & 5 & 15,6 & 3 & 9,4 & & & & \\
\hline Pendidikan & & & & & $1,000^{\mathrm{a}}$ & 1,16 & 0,35 & 2,67 \\
\hline Dasar (tidak sekolah,SD,SMP) & 10 & 31,3 & 9 & 28,1 & & & & \\
\hline Tinggi (SMA, Diploma) & 22 & 68,7 & 23 & 72,9 & & & & \\
\hline Pendapatankeluarga & & & & & $1,000^{\mathrm{a}}$ & 1,13 & 0,43 & 3,19 \\
\hline Rendah (<UMR) & 18 & 56,2 & 17 & 53,2 & & & & \\
\hline Cukup ( $\geq$ UMR) & 14 & 43,8 & 15 & 46,8 & & & & \\
\hline Pengetahuan $\boldsymbol{R F}$ & & & & & $0,000^{\mathrm{a}^{*}}$ & 10,23 & 3,76 & 27,75 \\
\hline Rendah $(\leq 60)$ & 19 & 59,4 & 4 & 12,5 & & & & \\
\hline Cukup & 13 & 40,6 & 28 & 87,5 & & & & \\
\hline Sikap $R F$ & & & & & $0,003^{\mathrm{a}^{*}}$ & 5,66 & 2,17 & 21,67 \\
\hline Kurang $(\leq 60)$ & 22 & 68,7 & 9 & 28,1 & & & & \\
\hline Cukup & 10 & 31,3 & 23 & 72,9 & & & & \\
\hline
\end{tabular}

${ }^{a} U$ ji Chi-Square Continuity Correction

*Hubungan bermakna

\section{PEMBAHASAN}

\section{Karakteristik Subjek Penelitian}

Stunting adalah masalah kurang gizi kronis atau gangguan pertumbuhan yang terjadi dalam waktu cukup lama ${ }^{4}$. Keadaan stunting diketahui dengan melihat nilai $z$-score $\mathrm{PB} / \mathrm{U}$ apabila memiliki nilai $z$-score $P \mathrm{~B} / \mathrm{U}$ kurang dari $-2 \mathrm{SD}^{23}$. Stunting paling berisiko terjadi pada masa dua tahun pertama usia anak, yang merupakan masa dimana anak mengalami perkembangan otak dan pertumbuhan linear.
Berdasarkan data, subjek pada kedua kelompok baduta paling banyak berusia $13-24$ bulan dan berjenis kelamin perempuan. Pada kelompok stunting didapatkan data Zscore $\mathrm{PB} / \mathrm{U}$ kurang dari -2 SD dan pada kelompok kontrol didapatkan data Zscore PB/U diatas -2 SD. Seluruh subjek dalam penelitian ini tidak sedang mengalami infeksi dan responden bersedia mengikuti penelitian ini. Keseluruhan responden merupakan ibu rumah tangga yang mengasuh anaknya sendiri. 


\section{Hubungan Pengetahuan Responsive Feeding dengan Kejadian Stunting}

Nilai p value dari Uji Chi Square pengetahuan RF dengan kejadian stunting pada baduta sebesar 0,000 sehingga dapat disimpulkan terdapat hubungan tingkat pengetahuan ibu mengenai RF dengan kejadian stunting usia 6-24 bulan di Wilayah Kerja Puskesmas Bandarharjo Semarang Utara. Berdasarkan nilai Odds Ratio (OR) ibu berpengetahuan RF rendah 10,2 kali anaknya berisiko mengalami stunting dibandingkan dengan ibu berpengetahuan RF cukup.

Pengetahuan RF pada kelompok kasus memiliki skor lebih rendah daripada kelompok kontrol pada poin cara meningkatkan pemberian makan, memberikan contoh kebiasaan sehat, memberikan makan secara aktif, syarat menghidangkan makanan, lingkungan yang dibutuhkan dalam memberi makan, cara memberi makan secara responsif ketika anak sakit, cara menyiasati penolakan makan, dan ketika anak menolak makan. Kelompok kasus memiliki skor yang lebih tinggi daripada kelompok kontrol pada poin cara memberi makan secara responsif saat masa pemulihan dan cara memberi makan responsif ketika nafsu makan menurun.

Cara meningkatkan pemberian makan pada anak dengan pelan, sabar, tanpa paksaan. Pengetahuan pada kelompok stunting pada poin ini lebih rendah dibandingkan kelompok kontrol terutama pada cara anak agar mau menghabiskan makanannya tanpa paksaan. Pada kelompok kontrol, ibu lebih mengetahui bagaimana cara membujuk anak agar mau menghabiskan makanan.

Memberikan contoh makanan sehat akan membentuk kebiasaan anak lebih memilih sayur dan buah, begitu sebaliknya ${ }^{24,25}$. Pengetahuan pada kelompok stunting pada poin ini lebih rendah dibandingkan kelompok kontrol dalam hal memperhatikan bagaimana dan fungsi makanan sehat untuk anak. Pada kelompok kontrol, ibu lebih mengetahui bahwa makanan sehat adalah kebutuhan anak yang harus dipenuhi.

Makanan untuk anak harus makanan yang sehat, memiliki rasa (berbumbu), dan berkembang sesuai dengan usianya baik porsi, tekstur, maupun frekuensinya. Pengetahuan pada poin porsi, tekstur, dan frekuensi dalam memberikan MP ASI kepada anak pada kelompok stunting lebih rendah dibandingkan kelompok kontrol. Pada kelompok kontrol, ibu mampu menjawab lebih baik mengenai pentingnya menyesuaikan porsi, tekstur, dan frekuensi menurut usia dan tekstur pertama kali MP ASI diberikan kepada anak.

Lingkungan dalam memberikan makanan yang sesuai akan membuat anak tahu apa yang harus dilakukan dan dapat mengadaptasi kedalam kebiasaannya ${ }^{26}$. Pada kelompok stunting, pengetahuan mengenai jadwal makan dan suasana pada saat memberikan makan lebih rendah dibandingkan kelompok kontrol. Pada kelompok kontrol, ibu lebih mengetahui pentingnya jadwal makan dan keamanan lingkungan pada saat memberikan makan.

Pemberian makan secara responsif diperlukan pada saat anak dalam kondisi sakit yang tidak hanya fokus pada kuantitas dan kualitas makanan dan frekuensi pemberian makan ${ }^{27}$. Pada kelompok stunting, pengetahuan pentingnya tetap memberikan makan pada saat anak kesulitan menelan dan asupan cairan lebih rendah dibandingkan kelompok kontrol. Pada kelompok kontrol, ibu lebih mengetahui bahwa anak tetap harus diberikan makan meskipun ada kesulitan menelan dan meningkatkan asupan cairan

Menyiasati adanya penolakan makan dan merespon ketika anak menolak makan dapat berefek pada pembatasan makan yang secara tidak sadar oleh ibu jika ibu salah menafsirkan ${ }^{28}$. Pengetahuan pada kelompok stunting pada poin ini lebih rendah dibandingkan kelompok kontrol dalam hal memperhatikan cara menarik minat anak terhadap makanan. Pada kelompok kontrol, ibu lebih mengetahui cara meningkatkan ketertarikan anak pada makanan.

Item pengetahuan dengan kesalahan tertinggi pada kelompok kasus mengenai cara dalam meningkatkan pemberian makan, hanya $18,7 \%$ ibu menjawab benar. Item pengetahuan dengan kesalahan tertinggi pada kelompok kontrol mengenai pemberian ASI pada saat penurunan nafsu makan, hanya $43,8 \%$ ibu menjawab benar.

Hasil penelitian ini hampir sama dengan penelitian Intan di Karawang yang menunjukkan bahwa pengetahuan RF ibu memiliki hubungan dengan pemberian makan yang baik kepada anak. Pengetahuan yang kurang mengenai RF meliputi keanekaragaman makanan, cara memberikan makan secara aktif, lingkungan yang dibutuhkan, respon ketika adanya penolakan makan dari anak, memberikan makan pada saat anak sakit dan dalam masa pemulihan, dan menghidangkan makanan kepada anak memiliki dampak terhadap nafsu makan anak dan status gizinya ${ }^{29}$.

Hasil penelitian ini hampir sama dengan penelitian yang dilakukan oleh Mawarni di Kota Surakarta dan oleh Tia di Wonosari, yang menyatakan bahwa terdapat hubungan pengetahuan ibu tentang pemberian makan anak dengan status gizi baduta usia 6-24 bulan ${ }^{30}$. Penelitian ini sejalan didukung dengan penelitian di pedesaan dan perkotaan yang menyatakan bahwa pengetahuan gizi ibu merupakan faktor risiko kejadian stunting pada anak dibawah lima tahun ${ }^{7,31}$. Berdasarkan penelitian 
sebelumnya, pengetahuan yang baik tentang gizi dapat memberikan makanan yang tepat bagi anaknya sehingga anak dapat tumbuh dan berkembang dengan baik sesuai usianya dan ketidaktahuan mengenai informasi tentang gizi dapat menyebabkan kurangnya mutu atau kualitas gizi makanan keluarga khususnya makanan yang dikonsumsi anak ${ }^{32-34}$.

Pengetahuan merupakan faktor tidak langsung yang berpengaruh terhadap status gizi baduta dan memiliki peran penting. Pengetahuan seseorang mengenai kesehatan yang cukup akan dapat mengetahui berbagai macam gangguan kesehatan yang mungkin akan timbul sehingga dapat dicari pemecahannya ${ }^{35}$. Hal ini sejalan dengan soetjiningsih yang menyatakan bahwa gangguan gizi terjadi karena pengetahuan yang kurang mengenai kebutuhan, makanan tambahan bergizi, dan kemiskinan sehingga kurang mampu menyediakan makanan yang bergizi ${ }^{36}$. Akibatnya akan terjadi penurunan konsumsi makan baduta. Pengetahuan mengenai gizi merupakan proses awal dalam perubahan perilaku peningkatan status gizi, sehingga pengetahuan merupakan faktor internal yang mempengaruhi perubahan perilaku. Pengetahuan ibu tentang gizi akan menentukan sikap dan perilaku ibu dalam menyediakan makanan untuk anaknya dan dapat menyediakan makanan dengan jenis dan jumlah yang tepat agar anak dapat tumbuh dan berkembang secara optimal, sehingga dapat menjadi faktor protektif ${ }^{37-39}$.

\section{Hubungan Sikap Responsive Feeding dengan Kejadian Stunting}

Kesulitan dalam menumbuhkan minat anak untuk makan adalah salah satu masalah terbesar di pedesaan dan perkotaan di Sri Lanka yang dapat dilihat dari pola pemberian makan yang tidak optimal seperti pemberian makan yang terkontrol dan menyenangkan. Sedangkan penelitian di Anuradhapura memperlihatkan bahwa pengetahuan mengenai MP ASI dan persiapannya cukup, tetapi pengetahuan dan kemampuan mengenai responsive feeding sangat rendah ${ }^{40}$. Tingkat pengetahuan ibu memengaruhi sikap dan perilaku dalam memilih bahan makanan, yang lebih lanjut akan memengaruhi keadaan gizi keluarganya ${ }^{41}$.

Terdapat hubungan sikap ibu RF dengan kejadian stunting usia 6-24 bulan di Wilayah Kerja Puskesmas Bandarharjo Semarang Utara ( $\mathrm{p}=0,003)$. Berdasarkan nilai Odds Ratio (OR), ibu dengan sikap RF kurang sesuai memiliki risiko 5,6 kali lebih besar anaknya mengalami stunting dibandingkan dengan ibu dengan sikap RF cukup. Item sikap dengan skor terendah pada kelompok kasus mengenai pengaturan rancangan waktu dan tempat pemberian makan dengan skor minimal 1 (sangat tidak setuju) sebanyak $56 \%$ responden dan skor maksimal 5 (sangat setuju) sebanyak $3 \%$ responden.
Skor sikap kelompok stunting secara keseluruhan lebih rendah dibandingkan kelompok kasus meliputi poin waktu dalam pemberian makan responsif, cara aktif memberi makan secara responsif, memberi makan ketika anak menolak makan dan menyiasati penolakan makan, pemberian makan ketika anak sakit dan dalam masa pemulihan, syarat menghidangkan makanan, cara meningkatkan pemberian makan, pemberian makan saat nafsu makan anak menurun dan dalam memberikan contoh makanan sehat. Namun pada poin pernyataan tertentu, kelompok kasus memiliki skor sikap yang lebih baik daripada kelompok kontrol pada poin memberi makan pada waktu dan tempat yang sama, pemilihan jenis makanan yang sesuai untuk anak.

Sebuah penelitian kualitatif di Semarang menyatakan bahwa RF belum dapat dilakukan secara menyeluruh dilatarbelakangi salah satunya adalah kurangnya pendidikan gizi ibu semasa hamil dan menyusui ${ }^{42}$. Pengetahuan dan sikap gizi ibu memiliki hubungan positif terhadap skor konsumsi anak yang nantinya dapat meningkatkan atau memperbaiki status gizi anak. Selain itu, sebuah penelitian mengatakan bahwa keuntungan jangka pendek RF adalah meningkatnya pemberian tanda lapar dan kenyang secara jelas dan sikap yang responsif. Sedangkan jangka panjang adalah meningkatnya psikososial, kemampuan kognitif dan berbicara, dan juga pertumbuhan yang sehat dan bergizi ${ }^{43}$.

Menurut penelitian oleh Intan Rahma, sikap ibu berhubungan dengan praktik pemberian makan yang baik, yang dapat dilihat dari baiknya responbilitas sehingga meningkatkan minat dan nafsu makan anak $^{29,44}$. WHO menyatakan apabila RF tidak diberikan kepada anak sesuai pedoman yang telah diterbitkan, maka akan berisiko stunting. Apabila perilaku makan yang tidak responsif, di mana orang tua memiliki peraturan dalam memberikan makan tanpa menanggapi sinyal anak hal ini akan berkaitan dengan kegagalan pertumbuhan ${ }^{13}$. Pada penelitian ini sikap ibu yang kurang paling banyak terdapat pada kelompok kasus dan kemungkinan memiliki praktik pemberian makan yang kurang baik sehingga memiliki dampak pada pertumbuhan anak dalam jangka waktu yang panjang. Hal yang mungkin melatarbelakangi sikap kurang sesuai pada kelompok stunting adalah pengetahuan selama masa kehamilan dan menyusui, namun dalam penelitian ini tidak diteliti karena keterbatasan penelitian.

Pengetahuan yang cukup tanpa diikuti sikap untuk bertindak, tidak dapat merubah dan memperbaiki gangguan gizi pada $\operatorname{anak}^{45}$. Pengetahuan dan sikap yang cukup diperlukan untuk memenuhi kebutuhan dan rekomendasi gizi anak melalui praktik pemberian makan untuk mencapai status gizi yang optimal. 


\section{Hubungan Panjang Badan Lahir dengan Kejadian Stunting}

Hasil penelitian ini didapatkan bahwa tidak ada hubungan antara berat badan lahir dengan kejadian stunting dengan nilai $\mathrm{p}=0.802$. Meskipun tidak terdapat hubungan, penelitian ini menunjukkan bahwa subjek memiliki panjang badan lahir yang kurang lebih banyak pada kelompok kasus berdasarkan analisis univariat.

Penelitian ini tidak sejalan dengan penelitian di Kupang, Bekasi, dan Surabaya yang menyatakan bahwa baduta dengan panjang badan lahir rendah merupakan salah satu faktor dengan risiko 4 kali lebih besar mengalami kejadian stunting dibandingkan dengan baduta dengan panjang badan lahir normal $^{34,46,47}$. Namun sejalan dengan penelitian di Semarang Timur yang menyatakan bahwa panjang badan lahir bukan merupakan faktor risiko dari kejadian stunting. Anak dengan panjang badan lahir pendek menunjukkan kurangnya gizi yang diasup Ibu selama masa kehamilan, sehingga pertumbuhan janin tidak optimal yang mengakibatkan bayi yang lahir memiliki panjang badan lahir yang rendah ${ }^{48}$. Faktor asupan dan penyakit memegang peranan yang menentukan apakah anak yang lahir dengan panjang badan lahir rendah akan tetap stunting selama masa hidupnya atau berhasil mencapai catch-up grow yang maksimal ${ }^{49}$.

Berdasarkan observasi, lingkungan tempat penelitian dekat dengan laut dan tinggi polusi. Timbal merupakan salah satu yang menghambat pertumbuhan sehingga mungkin menjadi faktor risiko kejadian stunting pada subjek. Selain itu sanitasi lingkungan juga menjadi faktor risiko kejadian stunting menurut beberapa penelitian. Faktor lingkungan serta sanitasi lingkungan dalam penelitian ini tidak diambil sebagai variabel karena keterbatasan peneliti.

\section{Hubungan Riwayat Asupan Energi, Protein, dan Seng dengan Kejadian Stunting}

Hasil penelitian ini didapatkan bahwa tidak ada hubungan antara asupan energi, protein, dan seng dengan kejadian stunting dengan nilai $p$ berturut-turut adalah $\mathrm{p}=0,330, \mathrm{p}=0,430$, dan $\mathrm{p}=0,178$.

Penelitian ini menunjukkan tidak ada hubungan antara asupan energi dan asupan protein dengan kejadian stunting. Konsumsi energi dan protein rendah $(<80 \%)$ terbanyak ada pada kelompok stunting. Baduta membutuhkan karbohidrat bersumber dari serealia, tepung-tepungan, buah, sayur, dan produk olahan susu untuk memenuhi kebutuhan zat gizi selama masa pertumbuhan ${ }^{50}$. Konsumsi energi terbesar pada kedua kelompok penelitian yaitu dari susu formula dan bubur instan, hanya sebagian kecil yang mengonsumsi beranekaragam sumber karbohidrat.
Hasil penelitian ini sejalan dengan penelitian di Kabupaten Bima dan Kabupaten Bantul yang menyatakan bahwa asupan riwayat makan diantaranya asupan energi dan asupan protein tidak berhubungan dengan kejadian stunting pada anak usia 6-23 bulan ${ }^{8,51}$. Selain itu, hal ini juga sejalan dengan penelitian tentang karakteristik anak dengan status gizi akut dan kronis di perkotaan dan pedesaan di Indonesia yang menyimpulkan variabel konsumsi energi dan protein di perkotaan tidak berhubungan dengan status gizi kronis ${ }^{31,52,53}$.

Berdasarkan hasil penelitian, konsumsi seng rendah $(<80 \%)$ terbanyak pada kelompok stunting meskipun antara asupan seng dan kejadian stunting tidak terdapat hubungan. Hal ini tidak sejalan dengan penelitian di Brebes yang meyatakan adanya hubungan antara riwayat konsumsi seng dengan kejadian stunting anak dibawah dua tahun ${ }^{54}$. Hal ini disebabkan karena pada penelitian ini asupan makanan yang diperoleh hanya menggambarkan keadaan konsumsi sebulan lalu, sementara status gizi stunting merupakan akumulasi dari kebiasaan makan terdahulu, sehingga konsumsi hanya pada bulan tertentu tidak langsung mempengaruhi status gizi dari baduta. Selain itu faktor predisposisi terjadinya defisiensi seng adalah karena konsumsi dan absorbsi kurang, meningkatnya pengeluaran, uilisasi kurang, dan kebutuhan meningkat pada keadaan tertentu. Faktor-faktor yang mengatur absorbsi seng, antara lain serat dan fitat yang menghambat ketersediaan biologik seng. Selain itu nilai albumin dalam plasma merupakan penentu utama absorbsi seng. Absorbsi seng menurun bila nilai albumin darah menurun, misalnya dalam keadaan gizi kurang. Namun penelitian ini sejalan dengan penelitian di Bima yang menyatakan tidak adanya hubungan antara riwayat asupan seng dengan kejadian stunting ${ }^{8}$. Manifestasi defisiensi Seng yang khas pada anak adalah keterlambatan pertumbuhan.

\section{Hubungan Karakteristik Ibu dengan Kejadian Stunting}

Berdasarkan hasil uji chi-square menunjukkan bahwa nilai $p 0.773(p>0,05)$ hal ini berarti tidak terdapat hubungan antara usia ibu saat hamil dengan kejadian stunting. Hasil uji univariat menunjukkan ibu dengan usia hamil berisiko lebih banyak pada kelompok kasus meskipun tidak terdapat hubungan antara keduanya. Hal ini sejalan dengan penelitian di Kulon Progo Yogyakarta yang menyatakan bahwa tidak ada hubungan antara usia ibu saat hamil dengan kejadian stunting ${ }^{55}$. Kehamilan dengan umur kehamilan 20-35 tahun merupakan masa aman karena kematangan organ reproduksi dan mental untuk menjalani kehamilan serta persalinan sudah siap ${ }^{56}$. Usia ibu lebih berperan sebagai faktor psikologis terhadap kondisi seorang ibu dalam menerima 
kehamilannya, sehingga akan berpengaruh terhadap pola pengasuhan terhadap anak. Dalam faktor fisiologis usia ibu berpengaruh terhadap pertumbuhan janin, namun apabila terdapat asupan makanan yang seimbang yang mampu dicerna tehadap kondisi fisiologis seorang ibu akan memberikan dampak yang positif ${ }^{57}$.

Penelitian ini menunjukkan tidak ada hubungan antara tinggi badan ibu, ibu yang pendek lebih banyak ditemukan pada kelompok kasus dibanding kelompok kontrol. Hal ini menunjukkan adanya kecenderungan bahwa ibu yang pendek memiliki anak yang pendek dengan risiko 1,69 lebih besar dibandingkan ibu dengan perawakan normal. Penelitian ini sejalan dengan penelitian di Bima dan Gunungpati bahwa tidak ada hubungan yang bermakna antara faktor genetik dengan kejadian Stunting pada anak usia dibawah lima tahun ${ }^{58}$.

Orang tua pendek memiliki gen dalam kromosom yang membawa sifat pendek dan berpeluang besar untuk menurunkan sifat pendek tersebut kepada anaknya. Tetapi jika sifat pendek orang tua disebabkan oleh kekurangan zat gizi maupun patologis, maka sifat pendek tersebut tidak akan diturunkan kepada anaknya dan kemungkinan anak dapat tumbuh dengan tinggi badan normal. Dalam penelitian ini tidak melihat pada faktor yang mempengaruhi tinggi badan ibu. Berbeda dengan penelitian di Semarang Timur, Bantul, dan Aceh yang mengemukakan bahwa tinggi badan ibu berpengaruh terhadap kejadian stunting dan menjadi faktor risiko stunting ${ }^{51,54}$.

Hasil penelitian ini tidak menunjukkan adanya hubungan antara pendidikan dengan kejadian stunting $(\mathrm{p}=1,000)$. Pada kelompok kasus dan kontrol sebagian besar berpendidikan tingkat SMP dan SMA. Penelitian ini sejalan dengan penelitian di wilayah kerja Puskesmas Wonosari yang membuktikan tidak adanya hubungan antara pendidikan ibu dengan kejadian stunting ${ }^{30}$. Namun, tidak sejalan dengan penelitian di Banjarbaru dan kota Padang yang menyatakan adanya hubungan antara pendidikan ibu dengan kejadian stunting, dimana pendidikan akan mempengaruhi pola asuh yang akan diberikan kepada anak $^{59,60}$.

Penelitian ini menunjukkan tidak adanya hubungan antara pendapatan keluarga dengan kejadian stunting $(\mathrm{p}=1,000)$. Pada kelompok kasus memiliki pendapatan keluarga rendah ( $<\mathrm{UMR})$ terbanyak. Hal ini menggambarkan bahwa meskipun tidak bermakna, namun pendapatan keluarga terendah berada pada kelompok kasus. Keluarga dengan status ekonomi baik akan dapat memperoleh pelayanan umum yang lebih baik seperti pendidikan, pelayanan kesehatan, akses jalan, dan lainnya sehingga dapat memengaruhi status gizi anak ${ }^{61}$. Saat ini pendapatan keluarga tidak menentukan kualitas dan kuantitas asupan dalam sebuah keluarga dan tidak dapat menentukan pola asuh yang digunakan dalam mengasuh anak. Pendapatan tinggi tidak dapat menjamin terhindar dari kejadian stunting, hal ini disebabkan tidak sepenuhnya pendapatan dibelanjakan untuk kebutuhan pangan.

Penelitian ini sejalan dengan penelitian yang dilakukan oleh Anindita di Tembalang yang menyatakan tidak ada hubungan antara pendapatan keluarga dengan kejadian stunting ${ }^{62}$. Hal ini dikarenakan, saat ini pemerintah memperhatikan keluarga dengan status ekonomi rendah dengan adanya wajib belajar 12 tahun, pelayanan kesehatan untuk keluarga tidak mampu dan dapat memiliki sesuai dengan kemampuannya. Apabila keluarga dengan pendapatan rendah mampu mengelola makanan yang bergizi dengan bahan yang sederhana dan murah maka pertumbuhan bayi juga akan menjadi baik ${ }^{63}$. Hal ini juga didukung oleh penelitian oleh Hadi yang menunjukkan tingkat pendapatan keluarga tidak berhubungan dengan status gizi TB/U dikarenakan indikator tersebut gambaran status gizi masa lampau sedangkan variabel pendapatan merupakan rekaman waktu terdekat ${ }^{64}$.

\section{KESIMPULAN}

Ada hubungan antara pengetahuan responsive feeding dan sikap responsive feeding dengan kejadian stunting pada baduta usia 6-24 bulan di Wilayah Kerja Puskesmas Bandarharjo Semarang Utara. Ibu berpengetahuan RF rendah 10,2 kali anaknya berisiko mengalami stunting dibandingkan dengan ibu berpengetahuan RF cukup, sedangkan ibu dengan sikap RF kurang sesuai 5,6 kali anaknya berisiko mengalami stunting dibandingkan dengan ibu dengan sikap RF cukup.

\section{SARAN}

Perlunya edukasi mengenai cara meningkatkan pemberian makan, memberikan contoh kebiasaan sehat, memberikan makan secara aktif, syarat penghidangan makanan, lingkungan yang dibutuhkan dalam memberi makan, cara memberi makan secara responsif ketika anak sakit, cara menyiasati penolakan makan, dan ketika anak menolak makan khususnya pada kelompok kasus untuk meningkatkan pengetahuan dan sikap, serta mengedukasi pentingnya kuantitas dan kualitas makanan dalam memenuhi kebutuhan gizi baduta sehingga diharapkan dapat meningkatkan status gizi baduta.

\section{DAFTAR PUSTAKA}

1. Black RE, Allen LH, Bhutta ZA, Caulfield LE, de Onis M, Ezzati M, et al. Maternal and 
child undernutrition: global and regional exposures and health consequences. Lancet. 2008;371(9608):243-60.

2. LitbangKemenkes. Riset Kesehatan Dasar 2013. 2013;

3. IDAI. Rekomendasi praktik pemberian makan berbasis bukti pada bayi dan batita di Indonesia untuk mencegah malnutrisi. 2015;

4. Bambang MAW. Peranan Gizi dalam Siklus Kehidupan. Vol. 40. 2012. p. 631.

5. Anugraheni HS, Kartasurya MI. Faktor Risiko Kejadian Stunting pada Anak Usia 12-36 Bulan di Kecamatan Pati, Kabupaten Pati. J Nutr Coll. 2012;1(1):1-8.

6. Kusuma KE, Nuryanto. Faktor Risiko Kejadian Stunting pada Anak Usia 2-3 tahun (Studi di Kecamatan Semarang Timur). J od Nutr Coll. 2013;2(4):2013.

7. Nasikhah R. Faktor Risiko Kejadian Stunting Pada Balita Usia24-36 Bulan di Kecamatan Semarang Timur. Univ Diponegoro. 2014;127.

8. Hairunis MN, Rohmawati N, Ratnawati LY. Determinan Kejadian Stunting pada Anak Balita di Wilayah Kerja Puskesmas Soromandi Kabupaten Bima Nusa Tenggara Barat ( Determinan Incidence of Stunting in Children Under Five Year at Puskesmas Soromandi Bima district of West Nusa Tenggara ). e J Pustaka Kesehat. 2016;4(2):323-9.

9. Loya RRP, Nuryanto. Pola Asuh Pemberian Makan pada Balita Stunting Usia 6 - 12 Bulan di Kabupaten Sumba Tengah Nusa Tenggara Timur. J Nutr Coll. 2017;6(1).

10. Yati DY. Hubungan Pola Pemberian Makan dengan Stunting pada Balita Usia 36-59 bulan di Desa Mulo dan Wunung di Wilayah Puskesmas Wonosari. Universitas 'Aisyiyah; 2018.

11. Sari Edelstein, PhD R. Life Cycle Nutrition. Vol. 53, Journal of Chemical Information and Modeling. 2013. p. 1689-99.

12. Yabancı N, Kısaç İ, Karakuş SŞ. The Effects of Mother's Nutritional Knowledge on Attitudes and Behaviors of Children about Nutrition. Procedia - Soc Behav Sci. 2014;116:4477-81.

13. Engle P, Pelto G. Responsive feeding: implications for policy and program implementation. J Nutr. 2011;141:508-11.

14. UNICEF. Study of Parental Knowledge, Attitudes and Practices Related to Early Childhood Development. 2014;

15. Harbron J, Booley S, B N, CE D. Responsive feeding: establishing healthy eating behaviour early on in life. South African J Clin Nutr. 2013;26(3):S141-9.

16. Allen KL, Gibson LY, McLean NJ, Davis EA, Byrne SM, Argenti M, et al. Responsive Feeding and Child Undernutrition in Low- and Middle-Income Countries. Int $\mathrm{J}$ Behav Nutr Phys Act. 2011;100(1):1-10.

17. Aboud FE, Shafique S, Akhter S. A Responsive Feeding Intervention Increases Children's Self-Feeding and Maternal Responsiveness but Not Weight Gain. J Nutr. 2009;139(9):1738-43.

18. UNICEF. Supporting Families for Nurturing Care : Responsive Feeding. UNICEF; 2015.

19. Blaney S, Februhartanty J, Sukotjo S. Feeding practices among Indonesian children above six months of age: A literature review on their magnitude and quality (part 1). Asia Pac J Clin Nutr. 2015;24(1):16-27.

20. Dewi M, Aminah M. Pengaruh Edukasi Gizi terhadap Feeding Practice Ibu Balita Stunting Usia 6-24 Bulan (The Effect of Nutritional Knowledge on Feeding Practice of Mothers Having Stunting Toddler Aged 6-24 Months). Indones J Hum Nutr. 2016;3(1):1-8.

21. DinasKesehatan. Laporan PSG dan Laporan Bulanan Puskesmas. Kota Semarang; 2013.

22. Widyakarya Nasional Pangan dan Gizi (WNPG). In Jakarta: Lembaga Ilmu Pengetahuan Indonesia; 2004.

23. Kemenkes RI. Keputusan Menteri Kesehatan republik Inodnesia Nomor 1995/ Menkes/ SK/ XII/ 2010. Standar Antropometri Penilaian status Gizi. Kementeri Kesehat RI. 2010;

24. Skinner JD, Carruth BR, Bounds W, Ziegler P, Reidy K. Do Food-Related Experiences in the First 2 Years of Life Predict Dietary Variety in School-Aged Children? J Nutr Educ Behav. 2002 Nov 1;34(6):310-5.

25. Papas MA, Hurley KM, Quigg AM, Oberlander SE, Black MM. Low-income , African American Adolescent Mothers and Their Toddlers Exhibit Similar Dietary Variety Patterns. J Nutr Educ Behav. 2009;41(2):87-94.

26. Bremner JG, Fogel A. Blackwell Handbook of Infant Development. Wiley; 2009. (Wiley Blackwell Handbooks of Developmental Psychology).

27. Eshel N, Daelmans B, Mello C De, Martines J. Public Health Reviews Responsive parenting: interventions and outcomes. Vol. 30163. 2006.

28. Barlow SE. Expert Committee Recommendations Regarding the Prevention, Assessment, and Treatment of Child and 
Adolescent Overweight and Obesity: Summary Report. Pediatrics. 2007 Dec 1;120(Supplement 4):S164 LP-S192.

29. Nirmala IR, Februhartanty J, Ade L. Maternal Attributes Are Positively Associated with Feeding Practices of Children Aged 2-5 Years in West Java, Indonesia. J Nutr. 2016;22(2):191-205.

30. Agustiningrum T. Hubungan Karakteristik Ibu dengan Kejadian Stunting pada Balita Usia 24-59 Bulan di Wilayah Kerja Puskesmas Wonosari I. Universitas Aisyiyah Yogyakarta; 2016.

31. Aridiyah FO, Rohmawati N, Ririanty $M$. Faktor-Faktor yang Mempengaruhi Kejadian Stunting pada Anak Balita di Wilayah Pedesaan dan Perkotaan (The Factors Affecting Stunting on Toddlers in Rural and Urban Areas). e-Jurnal Pustaka Kesehat. 2015;3(1):163-70.

32. Widyawati W. Hubungan Tingkat Pengetahuan Ibu Balita mengenai Pemberian Makanan Pendamping ASI (MP-ASI) dengan Status Gizi pada Balita Usia 6-24 Bulan di Kelurahan Semanggi Kecamatan Pasar Kliwon Kota Surakarta. 2016.

33. Porajow GDM, Kapantow NH, Kawengian SES. Hubungan Antara Pengetahuan dan Sikap Ibu dengan Tindakan Pemberian Makanan Pendamping Air Susu Ibu (MP-ASI) pada Bayi Usia 6-12 Bulan di Puskesmas Tuminting Kota Manado. E J Heal. 2017;6(3):1-9.

34. Ni 'mah K, Nadhiroh SR. Faktor Yang Berhubungan Dengan Kejadian Stunting Pada Balita. Media Gizi Indones. 2015;10(1):13-9.

35. Notoatmodjo S. Promosi Kesehatan dan Perilaku Kesehatan. Jakarta: Rineka Cipta; 2012. 260 p.

36. Soetjiningsih. Tumbuh Kembang Anak. Jakarta: Penerbit Buku Kedokteran EGC; 2012.

37. Astari LD. Faktor-faktor yangBerpengaruh terhadap Kejadian Stunting Anak Usia 6-12 Bulan di Kab. Bogor. Institut Pertanian Bogor; 2014.

38. Siagian CM, Halisitijayani M. Mother's Knowledge On Balanced Nutrition to Nutritional Status of Children in Puskesmas (Public Health Center) In the District of Pancoran, Southern Jakarta 2014. Int J Curr Microbiol Appl Stud. 2015;4(7):815-26.

39. Haripin TS, Albiner S, Zulhaidah L, Evawany A. Improving Mothers ' Knowledge and Child Calorie Intake through Modified Growth Chart in Deli Serdang Distric, Indonesia. Int
J Innov Appl Stud. 2015;12(1):252-65.

40. Agampodi TC. Responsive feeding: the missing link in child malnutrition in Sri Lanka. Sri Lanka J Child Heal. 2014;43(1):53-4.

41. Suhardjo. Berbagai Cara Pendidikan Gizi. Jakarta: Bumi Aksara; 2013.

42. Febriani Reski Briliantika. Faktor determinan perilaku responsive feeding pada balita stunting usia 6 - 36 bulan. J Nutr Coll. 2016;5 Jilid I:120-9.

43. Black MM, Aboud FE. Responsive Feeding Is Embedded in a Theoretical Framework of Responsive Parenting. J Nutr. 2011;141(3):490-4.

44. Duncanson K, N GD, Burrows T, Holman B, Collins C. Parents ' Perceptions of Child Feeding: A Qualitative Study Based on the Theory of Planned Behavior. J Dev Behav Pediatr. 2013;34(4):227-36.

45. Soekirman. Ilmu Gizi dan Aplikasinya untuk Keluarga dan Masyakakat. Jakarta: Departemen Pendidikan Nasional; 2000.

46. Keo S, Woda RR, Padmosiwi WI, Cendana UN. Hubungan Antara Panjang Badan dan Stunting pada Balita di Wilayah Kerja Kecamatan Amarasi Kabupaten Kupang. Cendana Med J. 2016;7(2):123-34.

47. Umur A, Di B, Jaticempaka K, Amaliah N, Sari K, Suryaputri IY. Panjang Badan Lahir Pendek sebagai Salah Satu Faktor Determinan Keterlambatan Tumbuh Kembang Anak Umur 6-23 Bulan di Kelurahan Jaticempaka , Pondok Gede, Bekasi. J Ekol Kesehat. 2016;15(1):3-9.

48. Kusharisupeni. Peran Status Kelahiran terhadap Stunting pada Bayi: Sebuah Studi Prospektif. J Kedokt Trisakti. 2002;(23):7380.

49. Rahayu LS, Sofyaningsih M, HAMKA MPD. Pengaruh BBLR (Berat Badan Lahir Rendah) dan pemberian ASI eksklusif terhadap perubahan status stunting pada balita di Kota dan Kabupaten Tangerang Provinsi Banten. In.

50. Hardinsyah. Ilmu Gizi: Teori dan Aplikasi. Jakarta: Buku Kedokteran EGC; 2016.

51. Irwanti W. Riwayat Asupan Energi dan Protein yang Kurang Bukan Faktor Risiko Stunting pada Anak Usia 6-23 Bulan. J Gizi dan Diet Indones. 2014;2(3):150-8.

52. Kronis DAN, Dan D, Indonesia DI, Fuada N, Muljati S. Karakteristik Anak Balita dengan Status Gizi Akut dan Kronis di Perkotaan dan Perdesaan, di Indonesia (RISKESDAS 2010). J Ekol Kesehat. 2011;10(3):168-79. 
53. Hanum F, Khomsan A, Heryanto Y. Hubungan Asupan Gizi dan Tinggi Badan Ibu dengan Status Gizi Anak Balita. J Gizi dan Pangan. 2014;9(1):1-6.

54. Lestari W, Margawati A, Rahfiludin MZ. Faktor Risiko Stunting pada Anak Umur 6-24 bulan di Kecamatan Penanggalan Kota Subulussalam Provinsi Aceh. J Gizi Indones. 2014;3(1):37-45.

55. Astuti DK, Studi P, Gizi I, Kesehatan FI, Surakarta UM. Hubungan karakteristik ibu dan pola asuh gizi dengan kejadian balita. 2016;

56. S A, Suwoyo, Mahaendriningtyastuti. Karakteristik Bayi Berat Lahir Rendah Sampai Tribulan II Tahun 2009 di Kota Kediri. J Kesehat Suara Forikes. 2010;1(3):210-22.

57. Candra A. Hubungan Underlying Factors dengan Kejadian Stunting pada Anak 1-2 Tahun. Non Publ. 2011;1-12.

58. M AC, Subagio HW, Margawati A. Determinan kejadian stunting pada bayi usia 6 bulan di kota semarang. J Gizi Indones. 2016;

59. Sulastri D. Faktor Determinan Kejadian
Stunting pada Anak Usia Sekolah di Kecamatan Lubuk Kilangan Kota Padang. J Kesehat. 2012;36(1):39-50.

60. Rahayu A, Khairiyati L. Risiko Pendidikan Ibu Terhadap Kejadian Stunting Pada Anak 623 Bulan. Penelit Gizi dan Makanan (The J Nutr Food Res. 2014;37(2 Dec):129-36.

61. Bishwakarma R. Spatial inequality in child nutrition in Nepal: implications of regional context and individual/household composition. 2011.

62. Anindita P. Hubungan Tingkat Pendidikan Ibu, Pendapatan Keluarga, Kecukupan Protein \& Zinc Dengan Stunting (Pendek) Pada Balita Usia 6 - 35 Bulan Di Kecamatan Tembalang Kota Semarang. J Kesehat Masyarakat,. 2012;1(2):617-26.

63. Susilaningrum R, Nursalam, Utami S. Asuhan Keperawatan Bayi dan Anak. jakarta: Salemba Humanika; 2013.

64. Riyadi H, Khomsan A, S D, A F, Mudjajanto E. Studi tentang Status Gizi pada Rumah Tangga Miskin dan Tidak Miskin. J Gizi Indones. 2006;1. 